\title{
Vegetation Diversity and Soil Physico-chemical Properties Under Traditional Management of Rangeland in Eastern Ethiopia
}

\author{
Dargo Kebede Alemie ${ }^{1} \&$ Haftay Hailu Gebremedhin ${ }^{2}$ \\ ${ }^{1}$ School of Natural Resource Management and Environmental Sciences, Haramaya University, Ethiopia \\ ${ }^{2}$ School of Animal and Range Sciences, Haramaya University, Ethiopia \\ Correspondence: Dargo Kebede Alemie, Natural Resource Management and Environmental Sciences, Haramaya \\ University, Ethiopia. Tel: 251-913-048-904. E-mail: dargokebede@gmail.com
}

$\begin{array}{lc}\text { Received: July 30, } 2018 & \text { Accepted: January 31, } 2019 \quad \text { Online Published: April 15, } 2019 \\ \text { doi:10.5539/jas.v11n5p515 } & \text { URL: https://doi.org/10.5539/jas.v11n5p515 }\end{array}$

The research is financed by Ethiopian Institution of Agricultural Research.

\begin{abstract}
The changes of herbaceous vegetation (composition, diversity, richness, evenness, and biomass production) and soil physico-chemical attributes of Harshin rangelands, eastern Ethiopia were examined under continuously open grazed areas and three ages of enclosures group arranged along chronological sequence into: $<5$ years (young), 5-10 years (mid) and $>10$ years (old). The herbaceous species composition showed a clear pattern of difference between the enclosure and open access grazed areas with desirable species being more prevalent in the enclosures and the undesirable ones being dominant in the open access grazed areas. The principal component analyses (PCA) of herbaceous species composition were accounted distinct across the open grazing young, mid and old enclosure management types. The diversity, richness and biomass production of herbaceous species were significantly different in the study area. The principal component analysis (PCA) of soil physico-chemical attributes showed distinct separation in relation to open grazing and three age enclosure areas. Overall, we found that the increased biomass production in the old enclosures may threat the herbaceous species diversity by dominating by only few species and hence affected the plants which are susceptible for species inter-competition.
\end{abstract}

Keywords: species composition, biomass production, enclosures

\section{Introduction}

Quantifying the impact of livestock grazing on natural communities (forages) has become a major issue in the management of rangelands especially where grazing is very widespread and its impacts may be in conflict with conserving biodiversity (Friedel, Stuart-Hill, \& Walsh, 2004). Grazing animals may exert beneficial or mutual influences on the vegetation for their own good (Kamau, 2004). Livestock can exert a considerable change on the diversity, composition, structure, and development of native plant communities (Hailu, 2017). However, the degree of change is highly dependent upon the ecosystem and plant community, the current environmental conditions, and the intensity and timing of grazing (Milchunas \& Lauenroth, 1993). Large concentration of grazing animals may often have harmful effects on the plants because of selectivity and overgrazing (Kamau, 2004). Much of the literature indicates that the change has been more drastic and evident in ecosystems where native grazing ungulates were historically scarce or absent (Mcginty \& Banner, 2009). Grazing increased, reduced or lacked consistent effect on plant diversity (Kamau, 2004). These contrasting patterns of response have frequently been attributed to differences in grazing intensity, with greatest diversity expected at intermediate level of grazing (Grime, 1973). Usually diversity is low in environments with very low availability of resources (i.e. where few species can survive) and increases with increasing resource availability (Hailu, 2017). The impact of grazing on diversity differs along gradients of primary productivity (Milchunas \& Lauenroth, 1993), but there is no general consensus about the process involved in this interaction. Grazing intensity affects the quantity and quality of organic and mineralized materials that are delivered to the litter and soil as vegetative residues, urine, and manure (Abule, Snyman, \& Smit, 2007). Grazing also affects the quality of herbage in the sward and this ultimately impacts degradation rate of litter, soil organic matter, and soil nutrient 
mineralization rates (Allsopp, Laurent, Debeaudoin, \& Igshaan Samuels, 2007). Kamau (2004) predicted that grazing could change diversity in opposite ways in resource-poor versus resource-rich ecosystems.

Vegetation changes in response to livestock removal are occurred on prolonged temporal scales in semi-arid rangelands (Fuhlendorf, Engle, Elmore, Limb, \& Bidwell, 2012). The rangelands in eastern Ethiopia have been exposed to extensive livestock grazing pressures which have led to a reduction in vegetation cover and preferred grass species, depletion of soil nutrients and accelerated erosion (Kassahun, Snyman, \& Smit, 2008). In response to these declining rangeland resources, establishment of enclosures in communal rangelands used by pastoralists is a widespread practice in eastern Ethiopia. Napier and Desta (2011) outlined the types of rangeland enclosures in Somali region into three forms of enclosures: Private, Cooperative and community (established by community, NGOs and government facilitation). The enclosures used in the present study were established privately by individual pastoralist. According to Napier and Desta (2011), the driving factors for the emergence of private enclosures in the region are to secure dry season reserve for livestock in times of increasing scarcity of grazing species. Management of the enclosures are similar to some East African pastoralists and agro-pastoralists, which is protected from livestock grazing during the wet season and served as dry-season reserve pasture for an individual's own livestock (Angassa \& Oba, 2010; Verdoodt, Mureithi, \& Van Ranst, 2010).

Differences in plant diversity inside and outside of enclosures were observed for several community types in the Serengeti (Briske, Fuhlendorf, \& Smeins, 2003). Diversity declined in all enclosure while equitability dropped sharply, although species richness was not significantly different (Kamau, 2004). Milchunas, Sala, and Lauenroth (1988) attributed this to replacement by tall species in ungrazed areas formerly dominated by short species when the area was being grazed. Pattern diversity, rather than point diversity was found to be the major contributor of stand diversity. The exclusion of domestic livestock from grazed rangeland often initiates secondary succession. If left undisturbed this succession may culminate in a plant community with a relatively stable composition (Brand \& Goetz, 1986). Range managers have often used enclosures, cemeteries, churchyards and other areas inaccessible to livestock to determine the potential for improvement on grazed rangeland. According to Woldu and Mohammed Saleem (2000), floristic richness and the efficiency of the vegetation as an energy trapping system tends to decrease as aboveground biomass becomes concentrated in a few species. The opposite apparently occurs in the grazed sites. Hence, a greater aboveground herbaceous production and a greater grass height characterize ungrazed vegetation (Kamau, 2004).

The change of vegetation and soil physico-chemical characteristics following the establishment of enclosures from extensively managed rangelands in eastern Ethiopia has been a controversial issue. Some studies documented improvements in vegetation, soil and water infiltration inside enclosures (Yayneshet, Eik, \& Moe, 2009). The previous research in the present study area by Haftay, Yayneshet, Animut, and Treydte (2013) also noted the enclosures aged from five to eight years have positive vegetation changes in herbaceous species diversity and biomass production. In contrast, other studies reported site-specific and minor differences between protected and adjacent grazed areas (Brand \& Goetz, 1986). This indicates the need to interpret results of studies involving short and long-term livestock removal from rangelands in relation to specific influential factors (Simons \& Allsopp, 2007). However, researches on the herbaceous vegetation and soil physico-chemical changes following the establishments of rangeland enclosures management practices and the changes among the different enclosure ages in the semiarid rangelands of eastern Ethiopia are limited. Therefore, this study was designed to elucidate the changes of herbaceous vegetation (composition, diversity, richness, evenness, and biomass production) and soil physico-chemical characteristics among continuously open grazed areas and three chronological sequence age enclosures $(<5$ years, 5-10 years and $>10$ years).

\section{Method}

\subsection{Description of the Study Area}

The study was conducted in the Harshin rangelands of the Somali Regional State in Eastern Ethiopia located in $9^{\circ} 12^{\prime} \mathrm{N}$ and $43^{\circ} 31^{\prime} \mathrm{E}$ at about $950 \mathrm{~km}$ east of Addis Ababa (Figure 1). The rainfall in the district is bimodal with a short rainy season from April to May, and the main rainy season from June to August. The average minimum temperature is about $20{ }^{\circ} \mathrm{C}$ and the average maximum temperature is $35{ }^{\circ} \mathrm{C}$. The average annual rainfall is 560 $\mathrm{mm}$ (Haftay et al., 2013). 


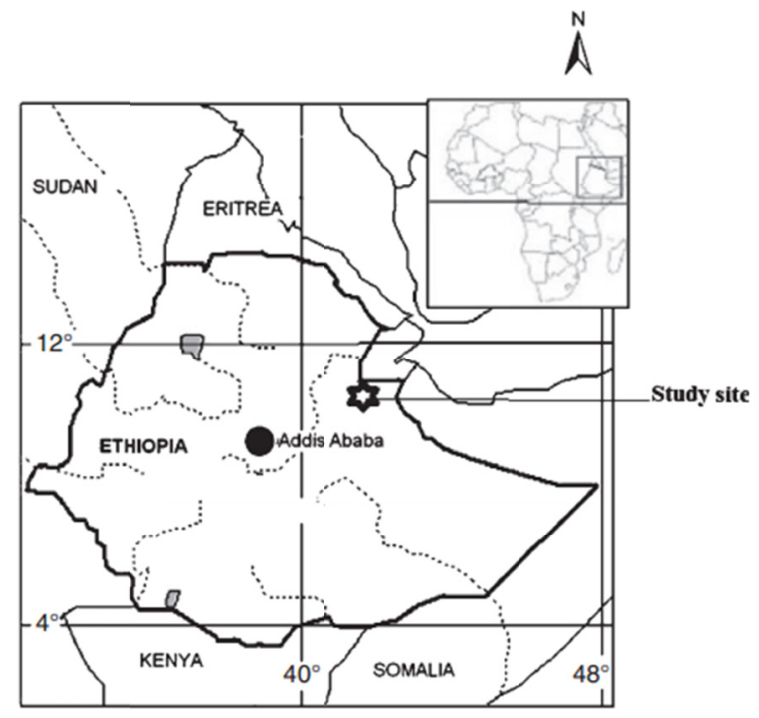

Figure 1. Map of Ethiopia with approximate location of study site (Asterisk)

\subsection{Selection of Study Site and Sampling Design}

Nine private enclosures (Total size about 18 ha approximately around 2 ha each) managed in similar way and served as dry-season reserve pastures for young and lactating animals were selected. Moreover, three adjacent communal open grazing areas about $40 \mathrm{~m}$ away from the margin of enclosures were selected systematically. The open grazed areas were exposed for grazing throughout the year. The ages of enclosures were arranged along age chronological sequence into three groups: $<5$ years (young), 5-10 years (mid) and $>10$ years (old). The opinion of the pastoralists was involved in evaluating enclosures of specific ages and the similarity among the enclosures' different age categories and open communal grazing areas in terms of their vegetation management, terrain, and land use to reduce the spatial variability of the vegetation across the study areas. $20 \mathrm{~m} \times 20 \mathrm{~m}\left(400 \mathrm{~m}^{2}\right)$ plots within each enclosure and each open-access communal grazing area. Within each $400 \mathrm{~m}^{2}$ plot, five (four at the corners and one at the center) $1 \mathrm{~m} \times 1 \mathrm{~m}^{\left(1 \mathrm{~m}^{2}\right)}$ quadrates were nested for recording the vegetation attributes. Sample measurements were done at similar times for all the study plots at the end of the rain season when the vegetation was at its peak flowering stage from September to October, 2013/2014.

\subsection{Data Collection and Analysis Methods}

The composition of herbaceous species was estimated in each quadrate. Nomenclature of the plant species followed the Flora of Ethiopia (Hedberg \& Edwards, 1995). The identified herbaceous species were grouped based on their life form into annuals and perennials. In addition, species were classified using desirability grouping methods i.e., highly desirable, desirable, less desirable and undesirable based on the opinion of herdsmen about the herbaceous species, vigor and palatability (Allsopp et al., 2007)

Diversity indices provide more information about community composition than simply species richness (i.e., the number of species present); they also take the relative abundances of different species into account (Indices, 2011). The Shannon diversity index $(\mathrm{H})$ is another index that is commonly used to characterize speciesdiversity in a community. Like Simpson's index, Shannon's index accounts for both abundance andevenness of the species present. The proportion of species i relative to the total number of species (pi) iscalculated, and then multiplied by the natural logarithm of this proportion (lnpi). The resulting product issummed across species, and multiplied by -1 (Indices, 2011):

$$
H^{\prime}=-\sum P i(\ln P i)
$$

where, $P i$ is the proportion of each species in the sample, and $\ln$ is the natural logarithms to the base e. The Shannon-Weiner Index $\left(H^{\prime}\right)$ was converted to effective number of species diversity using the following formula (Yayneshet et al., 2009):

$$
N 1=\operatorname{Exp}\left(H^{\prime}\right)
$$

where, $N 1$ is Effective number of species and $H^{\prime}$ is Shannon-Weiner function.Species equitability (evenness) was computed using the following formula:

$$
\text { Evenness }=H^{\prime} / \ln S
$$


where, $S$ is the total number of species. Species richness was also determined by counting all species with in the sample plots. Herbaceous aboveground biomass was estimated by harvesting at ground level using sickle from each $1 \mathrm{~m}^{2}$ quadrates. The cut samples were weighed immediately and $20-30 \%$ of the total weight retained for determination of dry matter content (oven drying at $105^{\circ} \mathrm{C}$ for 24 hours.

Soil samples (to depth of $10-15 \mathrm{~cm}$ ) were taken using an auger from each study plot at five nested quadrates per plot. Each set of five soil samples was mixed properly, air dried and passed through $2 \mathrm{~mm}$ sieve to make ready for analysis. Texture was determined using hydrometer method. Soil $\mathrm{pH}$ was measured using a 1:2.5 soil water relation extract method. Soil organic carbon was determined using walkey-black method (Baxter, Hastings, Law, \& Glass, 2008). The percent soil organic matter (SOM) was calculated by multiplying the percent organic carbon by a factor of 1.724 (Brady, Smith, Beam, \& Cravotta III, 1990). Total nitrogen was determined by the Kjeldahl method as described by (Campbell \& Racz, 1975). The exchangeable cations, viz sodium (Na), potassium (K), and calcium $(\mathrm{Ca})$ were extracted with ammonium acetate and analyzed using atomic absorption spectroscopy (Brady et al., 1990). Available phosphor (P) was analyzed using Olsen method (Campbell \& Racz, 1975), at Haramaya University Soil Chemistry Laboratory.

Data collected within each plot were averaged for statistical analysis. Herbaceous species composition was subjected to principal component analysis (PCA) ordination to explore the main components variation across the management types. Frequency and desirability of species composition among the open grazing area, young, mid and old ages of enclosures was analyzed using descriptive statistics. The distribution of species between open grazed and enclosures area were computed using the Sørensen's Similarity Index:

$$
I S S=2 c / a+b+2 c
$$

where, ISS is Sørensen's Similarity Index; $a$ representing the number of species unique to sample $a ; b$ representing the number of species unique to sample $b$; and $c$ representing the number of species in common. Data on vegetation diversity, richness, evenness, biomass production were subjected to one-way ANOVA to determine the changes by management type (open grazing area, young, mid and old ages of enclosures) on vegetation after Levene's equality of variance test using SPSS (version 20) software (Norusis, 2010). Differences were considered significant at $\mathrm{P}<0.05$. Soil physico-chemical attributes were subjected to principal component analysis (PCA), to explore the main components of variation in the soil attributes among the management types. Principal component analysis (PCA) ordination of vegetation and soil physico-chemical attributes was conducted using PAST (version 3) software (Ryan, Hammer, \& Harper, 2001).

\section{Results}

\subsection{Herbaceous Species Composition}

The principal component analyses (PCA) of herbaceous species composition were accounted distinct separation (PC $1=36.05 \% ; \mathrm{PC}=32.90 \%$ ) across the open grazing young, mid and old enclosure management types (Table 1). A total of 37 grass and forbs were identified in the study area (Table 1), of which $19 \%, 36 \%, 21 \%$ and $24 \%$ were highly desirable, desirable, less desirable and undesirable herbaceous species, respectively. From the identified herbaceous species about $38 \%$ and $62 \%$ were found in the open grazing and enclosure areas respectively (Table 2 ).

Sørensen's Similarity Index between the enclosures and the open access communal grazing areas were 0.48 . From the identified perennial herbaceous species about $62 \%$ were found in the enclosure areas. However, the numbers of annual herbaceous species in the open grazing and enclosure areas were the same. A total of 29 herbaceous species were found in the three ages category of enclosures. Of these $65.5 \%, 55.2 \%$ and $48.3 \%$ were found in the young, mid and old enclosures respectively.

Table 1. Principal component analysis (PCA) ordination of herbaceous species composition among open grazing area and young mid and old enclosure ages in Harshin rangelands of Eastern Ethiopia

\begin{tabular}{llllllll}
\hline Management type & Axis 1 & Axis 2 & Axis 3 & Axis 4 & PC & Eigenvalue & \% variance \\
\hline Open grazing & 0.08517 & 0.2339 & 0.9364 & 0.2472 & 1 & 0.0926291 & 36.052 \\
Young & -0.4288 & 0.8523 & -0.09929 & -0.2825 & 2 & 0.0845324 & 32.901 \\
Mid & 0.3534 & 0.3963 & -0.3365 & 0.7777 & 3 & 0.0491721 & 19.138 \\
Old & 0.827 & 0.2485 & -0.004153 & -0.5042 & 4 & 0.0305959 & 11.908 \\
\hline
\end{tabular}

Note. Young $=<5$ years; Mid 5-10 years; Old $=>10$ years. 


\subsection{Diversity and Biomass Production}

Diversity, richness and herbs biomass were significantly different across the open grazing area and three ages of enclosures (Table 2). However, the management types did not influence evenness of herbaceous species. The highest diversities were recorded in the young and mid enclosures respectively. The current study found that herbaceous biomass increases as enclosures age increases. Aboveground herbaceous biomass in the old enclosures was more than three times from the adjacent open grazed areas.

Table 2. Mean (Std.Error) of Diversity, Richness and Biomass of herbaceous species among open grazing area and young mid and old enclosure ages in Harshin rangelands of Eastern Ethiopia

\begin{tabular}{llllll}
\hline \multirow{2}{*}{ Vegetation Attributes } & \multicolumn{5}{c}{ Management Types } \\
\cline { 2 - 6 } & Open grazing & Young & Mid & Old & P \\
\hline Diversity & $8.22(0.81)$ & $13.86(0.56)$ & $11.78(0.32)$ & $9.76(1.09)$ & 0.004 \\
Richness $/ \mathrm{m}^{2}$ & $9.67(1.20)$ & $15.67(0.67)$ & $13.67(0.33)$ & $11.67(1.3)$ & 0.012 \\
Evenness & $0.85(0.02)$ & $0.89(0.02)$ & $0.88(0.04)$ & $0.88(0.02)$ & 0.573 \\
Biomass $\left(\mathrm{g} / \mathrm{m}^{2}\right)$ & $163.91(43.9)$ & $231.9(26.75)$ & $370.38(27.16)$ & $570.88(56.96)$ & 0.000 \\
\hline
\end{tabular}

Note. Young $=<5$ Years; Mid 5-10 Years; Old= $>10$ Years; $\mathrm{P}=$ Probability Value.

\subsection{Soil Physico-chemical Attributes}

The principal component analyses (PCA) of soil physico-chemical attributes were accounted distinct separation among the open grazing and three age enclosure areas with principal component 1 about $72.37 \%$ and eigenvalue about 15.66 and principal component 2 about $22.17 \%$ and eigenvalue about 4.80 . Moreover, PCA ordination within vegetation variables of sample plot were showed distinct separation with principal component 1 accounted about $53.06 \%$ and eigenvalue about 17.96and principal component 2 accounted about $25.03 \%$ and eigenvalue about 8.47 of the totals explained variance in relation to the open grazing area and three ages of enclosures in Harshin rangelands of Eastern Ethiopia (Figure 2). Principal component 1 defines a gradient from sample plots with higher soil $\mathrm{P}$ content than sample plots with high soil CEC. Principal component 2 defines a gradient from sample plots with greater $\mathrm{Ca}$ than sample plots with soil $\mathrm{P}$ and CEC.

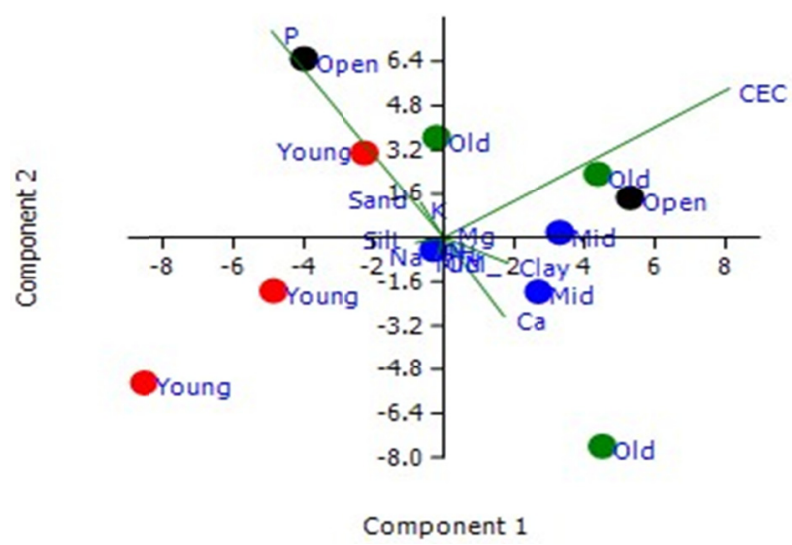

Figure 2. Principal component analysis (PCA) ordination diagram based on Soil physico-chemical characteristics among open grazing area and young mid and old enclosure ages in Harshin rangelands of Eastern Ethiopia

Note. Open denotes sample plot in the open grazing area; Young $=$ enclosure $<5$ years; Mid $=$ enclosure $5-10$ years; Old $=$ enclosure $>10$ years; CEC: Cations Electrical Conductivity, N: Total nitrogen, Na: sodium, K: potassium, Ca: calcium, P: phosphor, $\mathrm{Mg}$ : magnesium.

\section{Discussion}

Grazing intensity is the major factor influencing vegetation distribution in the semi-arid ecosystem. Sørensen's Similarity Index in relation to the management systems showed that the identified species had clear pattern of distributions between the management systems. From the total identified herbaceous species about $48 \%$ were 
commonly distributed over the management systems. The species of Cenchrus ciliaris, Setaria verticillata and Indigo feraarrecta were having high percentage composition in the open grazed communal areas while species Aristida adoensis, Cenchrus ciliaris and Cynodon dactylon were having a high percentage composition in the enclosure areas. The desirability of herbaceous species composition showed a clear pattern of difference between the enclosure and open access grazed areas with desirable species being more prevalent in the enclosures and the undesirable ones being dominant in the open access grazed areas (Table 3).

Highly desirable grass species such as Cenchrus ciliaris, Cynodon dactylonn and Panicum atrosanguineum were found in the enclosures and open access grazed areas. The presence of highly desirable species like C. dactylonin the open access grazed areas is because of their creeping nature of growth (Abate, Ebro, \& Nigatu, 2012; Gebremeskel, 2018). However, most of the vegetation species dominated the enclosures areas where undesirable forbs and less desirable grasses species like Setaria verticillata, Sporobolus marginatus, Hibiscus macranthus and Indigo feraarrecta dominated the open access communal grazing area.Therefore, overgrazing in the study area might have led to a loss of grass species that have important feeding value. Gemedo-Dalle, Maass, and Isselstein (2006) noted that the limited spatial distribution of the highly desirable forage grasses with grazing pressure might be an indicator of the deteriorating condition of rangelands.

The species composition based on frequency of occurrence of individual herbaceous species was generally low among the age of the enclosures. Grass species of Bothriochloa insculptawas the most dominant in the young age enclosure areas. While grass species of Aristida adoensis, Eragrostis superb, Cenchrus ciliaris and Bothriochloa insculpta were dominated in the mid age enclosure. In the old enclosures grass species of Aristida adoensis, Cynodon dactylon and Digitaria abyssinica were dominated.

Herbaceous species diversity, richness and biomass in the enclosures were greater than the openly grazed areas. Aboveground herbaceous biomass in the enclosures was more than twice of the adjacent grazed areas. This is attributed to the presence of high and unregulated grazing pressure on the freely accessed areas. Tefera, Snyman, and Smit (2007) reported that rangeland vegetation dynamics in the arid and semi-arid African rangelands have been subjected to controversy on equilibrium and non-equilibrium theories. 
Table 3. Percent composition of individual herbaceous species $\left(1 / \mathrm{m}^{2}\right)$ among open grazing area and young mid and old enclosure ages in Harshinrangelands of Eastern Ethiopia

\begin{tabular}{|c|c|c|c|c|c|}
\hline \multirow{2}{*}{ Species Name } & \multirow{2}{*}{$\begin{array}{l}\text { Life form } \\
\text { (Desirability) }\end{array}$} & \multicolumn{4}{|c|}{ Managements } \\
\hline & & Open grazing & Young & Mid & Old \\
\hline \multicolumn{6}{|l|}{ Grass } \\
\hline Andropogon abyssinicus & $\mathrm{P}(\mathrm{HD})$ & - & - & - & 7.5 \\
\hline Aristida adoensis & $\mathrm{P}(\mathrm{D})$ & - & 4.0 & 11.8 & 17.6 \\
\hline Bothriochloa insculpta & $\mathrm{P}(\mathrm{D})$ & - & 12.0 & 11.8 & 6.5 \\
\hline Cenchrus ciliaris & $\mathrm{P}(\mathrm{HD})$ & 16.76 & 1.6 & 10.2 & 7.4 \\
\hline Cynodon dactylon & $\mathrm{P}(\mathrm{D})$ & 2.35 & - & 9.5 & 13.9 \\
\hline Dactyloctenium aegyptium & $\mathrm{A}(\mathrm{D})$ & 5.88 & 8.0 & - & - \\
\hline Digitaria abyssinica & $\mathrm{P}(\mathrm{HD})$ & - & 4.8 & 6.3 & 12.0 \\
\hline Enteropogon simplex & A (D) & - & 8.0 & 7.9 & - \\
\hline Eragrostis schweinfurthii & $\mathrm{A}(\mathrm{D})$ & - & 8.0 & - & - \\
\hline Eragrostis superba & $\mathrm{P}(\mathrm{D})$ & & - & 11.8 & - \\
\hline Hyparrhenia rufa & $\mathrm{P}(\mathrm{D})$ & 4.71 & - & - & - \\
\hline Leucas microphylla & $\mathrm{P}(\mathrm{HD})$ & - & 0.8 & - & - \\
\hline Panicum atrosanguineum & $\mathrm{A}(\mathrm{HD})$ & 5.88 & 3.2 & - & 8.3 \\
\hline Setaria verticillata & $\mathrm{A}(\mathrm{LD})$ & 5.41 & - & - & - \\
\hline Sporobolus marginatus & $\mathrm{P}(\mathrm{HD})$ & 9.41 & - & - & - \\
\hline Tetrapogon tenellus & $\mathrm{A}(\mathrm{LD})$ & - & 3.2 & - & - \\
\hline Tragus berteronianus & $\mathrm{A}(\mathrm{LD})$ & 1.8 & - & & - \\
\hline Forbs & & & - & - & - \\
\hline Abutilon fruticasum & $\mathrm{P}(\mathrm{D})$ & 1.18 & 6.4 & - & - \\
\hline Acanthus eminens & $\mathrm{P}(\mathrm{UD})$ & 5.88 & - & - & 1.9 \\
\hline Anagallis arvensis & UI (UD) & 1.178 & - & - & - \\
\hline Asparagus racemosus & $\mathrm{P}(\mathrm{UD})$ & - & - & 2.4 & 1.9 \\
\hline Asystasia gangetica & $\mathrm{P}(\mathrm{LD})$ & - & 2.4 & 2.4 & 5.6 \\
\hline Blepharis ciliaris & $\mathrm{P}(\mathrm{LD})$ & - & - & - & 4.6 \\
\hline Conyza boranensis & $\mathrm{P}(\mathrm{UD})$ & - & - & 3.9 & - \\
\hline Crotalaria laburnifolia & $\mathrm{A}(\mathrm{D})$ & 1.17 & - & - & 3.7 \\
\hline Heliotropium cinerascens & UI (LD) & - & 7.2 & 5.5 & - \\
\hline Hibiscus macranthus & $\mathrm{P}(\mathrm{LD})$ & 8.24 & - & 3.9 & 8.3 \\
\hline Indigo feraarrecta & $\mathrm{P}(\mathrm{LD})$ & 12.94 & 5.6 & 3.1 & - \\
\hline Ipomoea ochracea & A (UD) & & 4 & - & - \\
\hline Ocimum urticifolium & $\mathrm{P}(\mathrm{D})$ & 2.35 & 3.2 & 3.1 & - \\
\hline Parthenium hysterophorus & $\mathrm{P}(\mathrm{UD})$ & 1.17 & - & - & - \\
\hline Psiadia incana & $\mathrm{P}(\mathrm{UI})$ & & - & - & 0.9 \\
\hline Senna didymobotrya & $\mathrm{P}(\mathrm{UD})$ & 1.17 & - & - & - \\
\hline Solanum somalense & $\mathrm{P}(\mathrm{UD})$ & - & 5.6 & 4.7 & - \\
\hline Sonchus oleraceus & $\mathrm{A}(\mathrm{LD})$ & - & 8.8 & 1.6 & - \\
\hline Tribulus terrestris & $\mathrm{A}(\mathrm{LD})$ & 4.71 & 3.2 & - & - \\
\hline Withania somnifera & A (UD) & 3.51 & - & - & - \\
\hline
\end{tabular}

Note. Young $=<5$ years; mid 5-10 years; Old $=>10$ years; $\mathrm{A}=$ annual, $\mathrm{P}=$ perennial; $\mathrm{HD}=$ highly desirable, $\mathrm{D}$ $=$ desirable, $\mathrm{LD}=$ less desirable. $\mathrm{UI}=$ unidentified, $\mathrm{UD}=$ Undesirable.

In equilibrium models vegetation dynamics are regulated by livestock grazing, and the vegetation moves in a predictable manner along a series of livestock densities showing a strong relationship between stocking rate and rangeland productivity (Briske, Bestelmeyer, Stringham, \& Shaver, 2008; Briske et al., 2003). The vegetation dynamics by the effect of management in the present study may exhibit typical of equilibrium model of vegetation change. With moderate levels of stress both species resistant to stress and the species susceptible to stress are able to survive and reproduce resulting in maximum species diversity and biomass productivities. Holechek, Gomes, Molinar, Galt, and Valdez (2000) noted that, in equilibrium model, grazing is a root cause of rangeland degradation where heavy stocking occurs. Inline to our study, Angassa and Oba (2010), and Haftay et al. (2013) had reported herbaceous species diversity and richness were higher in the enclosure than adjacent open 
access communal grazing areas. The high diversity, richness and biomass measured in the enclosures might be explained by the increased litter accumulation, improved soil organic matter and other nutrients inside the enclosures (Angassa, Oba, Treydte, \& Weladji, 2010). In the present study area high soil organic matter was found in the three ages of enclosures in relative to open access communal grazing areas.

In the present study, the vegetation change among the age of enclosures may be due to species inter/intra-competition. The herbaceous species diversity and richness were declined with increase age of the enclosures (i.e., young enclosures had more diversity than the old enclosures), in inverse, the herbage biomass increases with increases the age of enclosures. The moderate level of species competition at the early regeneration maybe attributes to survive and reproduce maximum species diversity and richness in the young enclosures, while the increased biomass production in the old enclosures may able to threat the herbaceous species diversity and richness by dominated only few species and affected the plants which are susceptible for species inter-competition. Zhang et al. (2005) suggested that short-term exclusion promoted herbaceous species richness, while long-term resting was not beneficial. The decline in species diversity and richness at a high biomass level is a major concern for rangeland conservation and management (Holmes, 2002). Grime (1973) hypothesized that species diversity could be plotted as a bell-shaped curve along gradients of environmental stress, as environmental stress increases, the species adapted to low-environmental stress lose their competitive advantage and species more resistant to environmental stress are allowed to increase in abundance.

\section{Conclusions}

Herbaceous species composition was accounted distinct separation across the open grazing, young, mid and old enclosure management types. High number of herbaceous species was identified in the open grazing area with $36.05 \%$ components variation. The highest diversities were recorded in the young and mid enclosures respectively. Aboveground herbaceous biomass in the old enclosures was more than three times from the open grazed areas. Overall, we found that increases the age of enclosures allowed maximum herbs biomass production that support the local pastoral economy in the Harshin rangelands of eastern Ethiopia. However, the increased biomass production in the old enclosures may able to threat the herbaceous species diversity by dominated only few species and affected the plants which are susceptible for species inter-competition. The soil physico-chemical attributes were accounted distinct separation among the open grazing and three age enclosure areas. From the selected soil attributes available phosphor (P), cations electrical conductivity (CEC) and calcium (Ca) were explored high variation components, contributed as sample plots with higher soil $\mathrm{P}$ content to sample plots high soil CEC and sample plots with greater Ca to sample plots with soil P and CEC.

\section{Acknowledgements}

The authors are grateful for the financial support given by Ethiopian Institution of Agricultural Research.

\section{References}

Abate, T., Ebro, A., \& Nigatu, L. (2012). Evaluation of rangeland in arid and semi-arid grazing land of South East Ethiopia. International Journal of Agricultural Sciences, 2(7), 221-234.

Abule, E., Snyman, H. A., \& Smit, G. N. (2007). Rangeland evaluation in the Middle Awash valley of Ethiopia: III. Relationships among soil and vegetation variables. Journal of Arid Environments, 70(2), $293-303$. https://doi.org/10.1016/j.jaridenv.2007.01.006

Allsopp, N., Laurent, C., Debeaudoin, L. M. C., \& Igshaan Samuels, M. (2007). Environmental perceptions and practices of livestock keepers on the Namaqualand Commons challenge conventional rangeland management. Journal of Arid Environments, 70(4), 740-754. https://doi.org/10.1016/j.jaridenv.2006.11.005

Angassa, A., \& Oba, G. (2010). Effects of grazing pressure, age of enclosures and seasonality on bush cover dynamics and vegetation composition in southern Ethiopia. Journal of Arid Environments, 74(1), 111-120. https://doi.org/10.1016/j.jaridenv.2009.07.015

Angassa, A., Oba, G., Treydte, A. C., \& Weladji, R. B. (2010). Role of traditional enclosures on the diversity of herbaceous vegetation in a semi-arid rangeland, southern Ethiopia. Livestock Research for Rural Development, 22(9).

Baxter, R., Hastings, N., Law, A., \& Glass, E. J. (2008). Organic carbon by wet oxidation (modified Walkely-Black method). Animal Genetics, 39(5), 561-563. https://doi.org/10.1111/j.1365-2052.2008. 01757.x

Brady, K., Smith, M., Beam, R., \& Cravotta III, C. (1990). Effectiveness of the Addition of Alkaline Materials at Surface Coal Mines in Preventing and Abating Acid Mine Drainage: Part 2. Mine Site Case Studies. 
Journal American Society of Mining and Reclamation, 1990(1), 227-242. https://doi.org/10.21000/JASMR 90010227

Brand, M. D., \& Goetz, H. (1986). Vegetation of Exclosures in Southwestern North Dakota. Journal of Range Management, 39(5), 434. https://doi.org/10.2307/3899446

Briske, D. D., Bestelmeyer, B. T., Stringham, T. K., \& Shaver, P. L. (2008). Recommendations for development of resilience-based state-and-transition models. Rangeland Ecology and Management, 61(4), 359-367. https://doi.org/10.2111/07-051.1

Briske, D. D., Fuhlendorf, S. D., \& Smeins, F. E. (2003). Vegetation dynamics on rangelands : a critique of. Journal of Applied Ecology, 40, 601-614. https://doi.org/10.1046/j.1365-2664.2003.00837.x

Campbell, L. B., \& Racz, G. J. (1975). Organic and inorganic P content, movement and mineralization of P in soil beneath a feedlot. Canadian Journal of Soil Science, 55(4), 457-466. https://doi.org/10.4141/cjss75-052

Friedel, M. H., Stuart-Hill, G. C., \& Walsh, D. (2004). What engages the interest of land managers in rangeland monitoring? African Journal of Range and Forage Science, 21(2), 89-100. https://oi.org/10.2989/ 10220110409485839

Fuhlendorf, S. D., Engle, D. M., Elmore, R. D., Limb, R. F., \& Bidwell, T. G. (2012). Conservation of Pattern and Process: Developing an Alternative Paradigm of Rangeland Management. Rangeland Ecology \& Management, 65(6), 579-589. https://doi.org/10.2111/REM-D-11-00109.1

Gebremeskel, K. (2018). Impact of Grazing Pressure around a Watering Point on Natural Pasture Quality in the Rangeland of North-Eastern Ethiopia. World Journal of Agricultural Sciences, 14(1), 12-16. https://doi.org/ 10.5829/idosi.wjas.2018.12.16

Gemedo-Dalle, Maass, B. L., \& Isselstein, J. (2006). Rangeland condition and trend in the semi-arid Borana lowlands, southern Oromia, Ethiopia. African Journal of Range \& Forage Science, 23(1), 49-58. https://doi.org/10.2989/10220110609485886

Haftay, H., Yayneshet, T., Animut, G., \& Treydte, A. C. (2013). Rangeland vegetation responses to traditional enclosure management in eastern Ethiopia. Rangeland Journal, 35(1), 29-36. https://oi.org/10.1071/ RJ12054

Hailu, H. (2017). Analysis of Vegetation Phytosociological Characteristics and Soil Physico-Chemical Conditions in Harishin Rangelands of Eastern Ethiopia. Land, 6(1), 4. https://doi.org/10.3390/land6010004

Holechek, J., Gomes, H., Molinar, F., Galt, D., \& Valdez, R. (2000). Short-duration grazing: the facts in 1999. Rangelands, 22(1), 18-22. https://doi.org/10.2307/4001516

Holmes, J. (2002). Diversity and change in Australia's rangelands: A post-productivist transition with a difference? Trans Inst Br Geogr, 27, 362-384.

Indices, D. (2011). Shannon's diversity index total number of species in the community (richness) proportion of. Diversity, 1-7.

Kamau, P. (2004). Forage Diversity and Impact of Grazing Management on Rangeland Ecosystems in Mbeere District, Kenya. Lucid, 36, 1-21. https://doi.org/10.1080/09670262.2012.683202

Kassahun, A., Snyman, H. A., \& Smit, G. N. (2008). Impact of rangeland degradation on the pastoral production systems, livelihoods and perceptions of the Somali pastoralists in Eastern Ethiopia. Journal of Arid Environments, 72, 1265-1281. https://doi.org/10.1016/j.jaridenv.2008.01.002

Mcginty, E. L., \& Banner, R. (2009). A Review of Livestock Grazing and Range Management in Utah. Utah State University, Salt Lake City, UT, USA.

Milchunas, D. G., \& Lauenroth, W. K. (1993). Quantitative effects of grazing on vegetation and soils over a global range of environments. Ecological Monographs, 63(4), 327-366. https://doi.org/10.2307/2937150

Milchunas, D. G., Sala, O. E., \& Lauenroth, W. K. (1988). A Generalized Model of the Effects of Grazing by Large Herbivores on Grassland Community Structure. The American Naturalist, 132(1), 87-106. https://doi.org/10.1086/284839

Napier, A., \& Desta, S. (2011). Review of Pastoral Rangeland Enclosures in Ethiopia.

Norusis, M. J. (2010). IBM SPSS Statistics 19 Core System-User's Guide (Statistics, 444).

Ryan, P. D., Hammer, Ø., \& Harper, D. A. (2001). Past: Paleontological Statistics Software Package for 
Education and Data Analysis-Palaeontol. Electronica, 4, 1-9. https://doi.org/10.1016/j.bcp.2008.05.025

Simons, L., \& Allsopp, N. (2007). Rehabilitation of Rangelands in Paulshoek, Namaqualand: Understanding vegetation change using biophysical manipulations. Journal of Arid Environments, 70(4), 755-766. https://doi.org/10.1016/j.jaridenv.2006.11.012

Tefera, S., Snyman, H. A., \& Smit, G. N. (2007). Rangeland dynamics in southern Ethiopia: (1) Botanical composition of grasses and soil characteristics in relation to land-use and distance from water in semi-arid Borana rangelands. Journal of Environmental Management, 85(2), 429-442. https://doi.org/10.1016/ j.jenvman.2006.10.007

Verdoodt, A., Mureithi, S. M., \& Van Ranst, E. (2010). Impacts of management and enclosure age on recovery of the herbaceous rangeland vegetation in semi-arid Kenya. Journal of Arid Environments, 74(9), 1066-1073. https://doi.org/10.1016/j.jaridenv.2010.03.007

Woldu, Z., \& Mohammed Saleem, M. A. (2000). Grazing induced biodiversity in the highland ecozone of East Africa. Agriculture, Ecosystems and Environment, 79(1), 43-52. https://doi.org/10.1016/S0167-8809 (99)00141-3

Yayneshet, T., Eik, L. O., \& Moe, S. R. (2009). The effects of exclosures in restoring degraded semi-arid vegetation in communal grazing lands in northern Ethiopia. Journal of Arid Environments, 73(4-5), 542-549. https://doi.org/10.1016/j.jaridenv.2008.12.002

Zhang, X., Aguilar, E., Sensoy, S., Melkonyan, H., Tagiyeva, U., Ahmed, N., ... Wallis, T. (2005). Trends in Middle East climate extreme indices from 1950 to 2003. Journal of Geophysical Research, 110(D22), 1-12. https://doi.org/10.1029/2005JD006181

\section{Copyrights}

Copyright for this article is retained by the author(s), with first publication rights granted to the journal.

This is an open-access article distributed under the terms and conditions of the Creative Commons Attribution license (http://creativecommons.org/licenses/by/4.0/). 